\title{
Anaerobic aniline degradation via reductive deamination of 4-aminobenzoyl-CoA in Desulfobacterium anilini
}

\author{
Sylvia Schnell and Bernhard Schink \\ L thrstuhl Mikrobiologie I, Eberhard-Karls-Universität, Auf der Morgenstelle 28, W-7400 Tübingen, Federal Republic of Germany
}

Received August 1, 1990/Accepted October 25, 1990

\begin{abstract}
The initial reactions involved in anaerobic aniline degradation by the sulfate-reducing Desulfobacterium anilini were studied. Experiments for substrate induction indicated the presence of a common pathway for aniline and 4-aminobenzoate, different from that for degradation of 2-aminobenzoate, 2-hydroxybenzoate, 4hydroxybenzoate, or phenol. Degradation of aniline by dense cell suspensions depended on $\mathrm{CO}_{2}$ whereas 4 aminobenzoate degradation did not. If acetyl-CoA oxidation was inhibited by cyanide, benzoate accumulated during degradation of aniline or 4-aminobenzoate, indicating an initial carboxylation of aniline to $4-$ aminobenzoate, and further degradation via benzoate of both substrates. Extracts of aniline or 4-aminobenzoategrown cells activated 4-aminobenzoate to 4-aminobenzoyl-CoA in the presence of COA, ATP and $\mathrm{Mg}^{2+}$. 4-Aminobenzoyl-CoA-synthetase showed a $K_{\mathrm{m}}$ for 4-aminobenzoate lower than $10 \mu \mathrm{M}$ and an activity of $15.8 \mathrm{nmol} \cdot \mathrm{min}^{-1} \cdot \mathrm{mg}^{-1} \cdot 4$-Aminobenzoyl-CoA was reductively deaminated to benzoyl-CoA by cell extracts in the presence of low-potential electron donors such as titanium citrate or cobalt sepulchrate $(2.1 \mathrm{nmol}$ - $\min ^{-1} \cdot \mathrm{mg}^{-1}$ ). Lower activities for the reductive deamination were measured with NADH or NADPH. Reductive deamination was also indicated by benzoate accumulation during 4-aminobenzoate degradation in cell suspensions under sulfate limitation. The results provide evidence that aniline is degraded via carboxylation to 4-aminobenzoate, which is activated to 4-aminobenzoyl$\mathrm{CoA}$ and further metabolized by reductive deamination to benzoyl-CoA.
\end{abstract}

Key words: Carboxylation $-4-\wedge$ minobenzoate - Benzoate - 4-Aminobenzoyl-CoA synthetase - 4-Aminobenzoyl-CoA reductase

Aniline is synthesized in large amounts to produce dyes, plastics, pesticides and other industrial products (Franck

Offprint requests to: S. Schnell and Stadelhofer 1987). Nitrobenzenes, which are used as solvents, oxidizers and blasting agents, are reduced to aniline derivatives under anaerobie conditions (Hallas and Alexander 1983). Arylamines are highly toxic and cause often severe pollution problems if discharged into natural waters. Several bacteria are known (Reber et al. 1979; Aoki et al. 1985; Wyndham 1986) which decompose aniline in the presence of oxygen, mostly via catechol as intermediate (Backofer et al. 1975; Janke et al. 1988). A denitrifying Paracoccus sp. catalypes anaerobic transformation and incomplete degradation of aniline (Bollag and Russel 1976). The lirst bacterium known to degrade aniline completely under anaerobic conditions is the sulfate-reducing Desulfobacterium anilini (Schnell et al. 1989). The present study elucidates the initial steps in anaerobic aniline degradation by this bactcrium.

\section{Materials and methods \\ Cultivation of Desulfobacterium anilini}

Strain Anil (DSM 4660) was grown in bicarbonate-buffered, sulfide-reduced brackish water minetal medium under a $\mathrm{N}_{2} / \mathrm{CO}_{2}$ atmosphere $(90 \% / 10 \%)$ in infusion bottlos ( $125 \mathrm{ml}$ ) sealed with latex septa. Growth conditions and medium composition have heen described previously in detail (Schnell et al. 1989). Aromatic substralcs were added successively at $0.5-1.0 \mathrm{mM}$ amounts from filtersterilized stock solutions stored under an $\mathrm{N}_{2}$ atmosphere.

Preparation of dense cell suspensions and cell-free extracts

Cells were harvested anaerobically by centrifugation at $3300 \mathrm{~g}$ for $40 \mathrm{~min}$ in the culture bottles in a rotor equipped with rubber adaptors. Cells were washed with medium without substrate and electron acceptor. For experiments with intact cells, pellets were suspended in medium to yield a final protein content of $0.5 \mathrm{mg} \cdot \mathrm{ml}^{-1}$. Cell-free extracts were prepared from similar suspensions in $\mathrm{N}_{2}$-sparged $50 \mathrm{mM}$ sodium phosphate buffer, $\mathrm{pH} 7.0$, containing $20 \mathrm{mM} \mathrm{MgCl} 2 \times 6 \mathrm{H}_{2} \mathrm{O}$ and $2.5 \mathrm{mM} \mathrm{1,4-dithiothreitol.} \mathrm{Cells}$ were broken in a cooled French pressure cell gassed with $\mathrm{N}_{2}$. The crude extract was centrifuged again in $\mathrm{N}_{2}$-gassed vals at $5000 \mathrm{~g}$ at $4^{\circ} \mathrm{C}$ to remove cell debris. 


\section{Enzyme assays}

Assays were performed in $2 \mathrm{ml}$ vials closed with butyl rubber septa and gassed with $\mathrm{N}_{2} / \mathrm{CO}_{2}$ or $\mathrm{N}_{2}$, depending on the buffer used. All additions and sampling were done with gas-tight Unimetrics microliter syringes.

For whole-cell experiments, the reaction mixture ( $1 \mathrm{ml}$ ) contained sulfide-reduced modium buffered with $30 \mathrm{mM}$ bicarbonate, $20 \mathrm{mM}$ sulfate, $0.5-1.0 \mathrm{mM}$ aromatic substrate, $0.25 \mathrm{mM}$ dithionite, and about $0.1 \mathrm{mg}$ cell protein per $\mathrm{ml}$. The $\mathrm{CO}_{2}$ dependence of" substrate degradation was studied in sulfide-reduced medium buffered with $10 \mathrm{mM}$ potassium phosphate, $\mathrm{pH} 7.2$, and prepared under $\mathrm{N}_{2}$ atmosphere. The $\mathrm{CO}_{2}$ content was checked in the headspace of strongly shaken medium by a gaschromatograph with thermal conductivity detector (Platen 1989). To remove bicarbonate and free $\mathrm{CO}_{2}$ from the growth medium, cells were washed twice and gassed with $\mathrm{N}_{2}$.

Acyl-CoA synthetase: The assay contained $0.5 \mathrm{mM}$ aromatic acid, $0.5 \mathrm{mM}$ CoASH, $1 \mathrm{mM}$ ATP, $20 \mathrm{mM} \mathrm{MgCl}, 2.5 \mathrm{mM}$ dithiothreitol, and about $0.17 \mathrm{mg}$ cell protcin in $\mathrm{N}_{2}$-gassed $50 \mathrm{mM}$ sodium pliosphate buffer, $\mathrm{pH} 7.0 \mathrm{in}$ a final volume of $1 \mathrm{~mL}$. In some experiments, acetyl-CoA, succinyl-CoA, ADP, and GTP were used instead of COASH and ATP.

Two different assays were used to measure 4-aminobenzoylCoA reductase activity. i) The acyl-CoA synthetase assay was amended with various reductants $0.5 \mathrm{mM}$ NADH, NADPH, reduced methyl viologen, benzyl viologen, titanium citrate, cobalt sepulchrate, anthraquinone 2,6-disulfonate, neutral red, safranin $\mathrm{T}$, bipyridyl, propylviologen sulfonate, FADH, formate, or hydrogen), either right at the beginning or after $2 \mathrm{~h}$ when sufficient amounts of 4-aminobenzoyl-CoA were formed. ii) Chemically synthesized 4 aminobenzoyi-CoA was added to a reaction mixture with cell extract and reductants. Controls were run with reaction mixtures either lacking cells or cell-ftee extract, or containing boiled cell extract (5 min at $100^{\circ} \mathrm{C}$ ).

Pyrophosphatase was assayed measuring the formation of orthophosphate (Herbert er af. 1971) from pyrophosphate. The assay was performed after Thebrath et al. (1989).

\section{Synthesis and quantification of benzoyi-COA}

Benzoyl-CoA was synthesized after Merkel et al. (1989), and purificd by HPLC. The spectrum of the purified fraction was the same as reported by Wobster et al. (1974). Benzoyl-CoA concentration was calculatcd using the extinction coefficient at $261 \mathrm{~nm}$ of $21.1 \mathrm{mM}^{-1}$ $\mathrm{cm}^{-1}$ (Webster et al. 1974).

\section{Analyses of substrates and products}

Samples were analysed with a Beckman System Gold high pressure liquid chromatograph equipped with a Merck LiChrospher $60 \mathrm{RP}$ select B column $(5 \mathrm{~mm} \times 12.5 \mathrm{~cm})$. The mobils phase contained $100 \mathrm{mM}$ ammonium phosphate buffer, $\mathrm{pH} 2.6$, and methanol. Various gradients were used between 10 and $70 \%$ methanol to separate ATP, AMP, COASH, aromatic acids, and acyl-CoA esters, at $1 \mathrm{ml}$ min $^{-1}$ flow rate. Samples of $20 \mu$ ] were injected with a Spark Promis I autosampler. A Beckman 167 scanning variable wavelength detector was used at the respective appropriate wavelength for each compound. Data were analysed by a computer program and quantified by comparison with external and internal standards of known composition. Peaks were identified by comparison of retention times and UV-spectra recorded by on-line spectral scans with standard samples.

\section{Assay for ${ }^{14} \mathrm{CO}_{2}$-carboxyl exchange}

${ }^{14} \mathrm{CO}_{2}$-carboxyl exchange or 4-aminobenzoate was assayed according to T'schech and Fuchs (1989), under strictly anaerobic con- ditions. The mixture contained $100 \mathrm{mM}$ Tris-HCl buffer, $\mathrm{pH} 6.9$, $2 \mathrm{mM}$ dithiocrythritol, $5 \mathrm{mM} \mathrm{NaHCO}, 2.5 \mathrm{mM}$ 4-aminobenzoate or 4-hydroxybenzoate, $0.5 \mathrm{mM} \mathrm{MnCl}, 20 \mathrm{mM}$ potassium phosphate, and $200 \mu \mathrm{l}$ cell extract (100 mg profein). The reaction was started arter $10 \mathrm{~min}$ incubation at $30^{\circ} \mathrm{C}$ with $1.5 \times 10^{4} \mathrm{~Bq}$ $\mathrm{NaH}^{14} \mathrm{CO}_{3}$. Samples $(200 \mu \mathrm{l})$ were withdrawn with syringes, stopped with $20 \mu 13 \mathrm{M}$ perchloric acid, and centrifuged. $150 \mu \mathrm{l}$ of the supernatant was added to $150 \mu 11 \mathrm{M} \mathrm{KHCO}_{3}$ solution, acidified with $50 \mu 110 \mathrm{~N}$ formic acid, and gassed for $15 \mathrm{~min}$ with $\mathrm{N}_{2} / \mathrm{CO}_{2}$ $(80 \% / 20 \%)$. The remaining acid-stable radioactivity was determined by liquid scintillation counting.

\section{Protein assay}

Protein was determined by the method of Bradford (1976) with bovine scrum albumin as standard.

\section{Results}

\section{Induction experiments}

Kinetics of substrate degradation were studied with dense cell suspensions grown with various substrates. Cells grown with 4-aminobenzoate immediately degraded 4aminobenzoatc $\left(19.3 \mathrm{nmol} \cdot \mathrm{min}^{-1} \cdot \mathrm{mg}^{-1}\right)$ and aniline (13.5 $\left.\mathrm{nmol} \cdot \mathrm{min}^{-1} \cdot \mathrm{mg}^{-1}\right)$ at comparably high initial rates. 2-Aminobenzoate, 2-hydroxybenzoate, 4-hydroxybenzoate, and phenol were degraded only after lag times of $4-7 \mathrm{~h}$ (Fig. 1). Colls grown with 2-aminobenzonte degraded only 2 -aminobenzoate immediately whereas aniline, 4-aminobenzoate, and phenol degradation was significantly delaycd. Phenol-grown cells immediately degraded phenol, 2-aminobenzoate, 2-hydroxybenzoate, and 4-hydroxybenzoate; aniline and 4-aminobenzoate were utilized very slowly. Cells grown with aniline degraded aniline, phenol, 2-aminobenzoate, 4-aminobenzoate, 2 -hydroxybenzoate and 4-hydroxybenzoate at nearly identical initial rates.

\section{$\mathrm{CO}_{2}$ dependence of aniline degradation}

Degradation of aniline, phenol, and 4-aminobenzoate was observed in $\mathrm{CO}_{2}$-free medium and for comparison with $30 \mathrm{mM}$ bicarbonate added. Degradation of aniline and phenol was significantly enhanced in the presence of $\mathrm{CO}_{2}$, whereas 4-aminobenzoate degradation was independent of $\mathrm{CO}_{2}$ (Fig. 2).

\section{Aniline and 4-aminobenzoate degradation in sulfate-limited or cyanide-inhibiled cell suspensions}

Degradation of aniline and 4-aminobenzoate was examined in dense cell suspensions washed twice in sulfate-free medium, and incubated without sulfate or with $1 \mathrm{mM}$ sulfate added. In the absence of sulfate, only $0.25 \mathrm{mM}$ aniline was degraded, and no aromatic product was formed. With $1 \mathrm{mM}$ sulfate added, $0.57 \mathrm{mM}$ aniline disappeared. Cells incubated with $1 \mathrm{mM}$ 4-aminobenzoate 

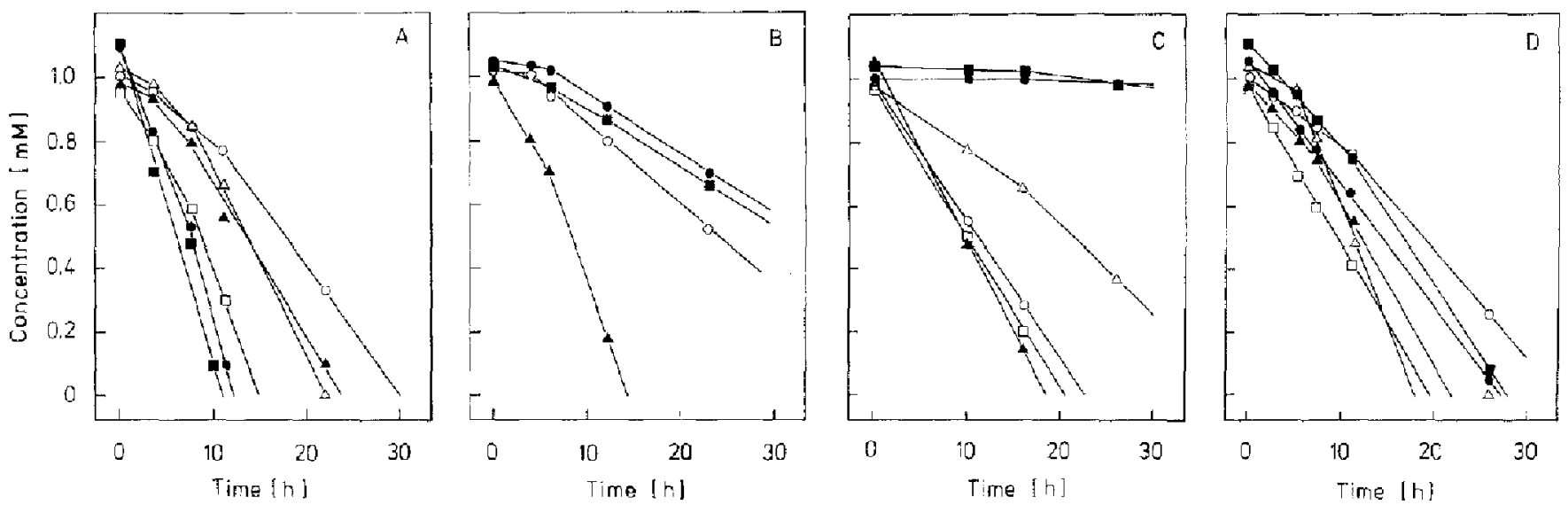

Fig. 1 A - D. Substrate degradation in dense cell suspensions grown with 4-aminobenzoate (A), 2-aminobenzoate (B), phenol (C) and aniline (D). Aniline, 4-aminobenzoalc, $₫$ 2-aminobenzaate, $O$ phenol, $\sqsubset$ 4-hydroxybenzoate, $\triangle$ 2-hydroxybenzoate

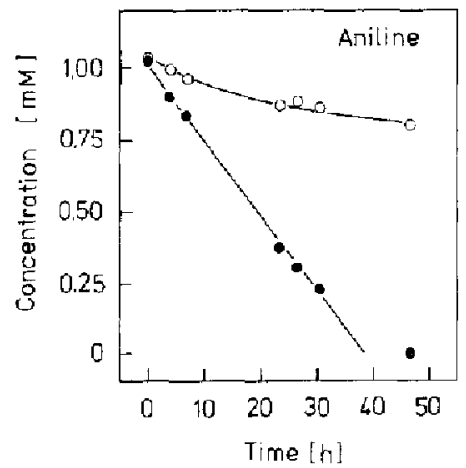

accumulated $0.22 \mathrm{mM}$ benzoate in the absence of sulfate, while $0.36 \mathrm{mM}$ 4-aminobenzoate disappeared.

In dense cell suspensions, aniline and 4-aminobenzoate degradation were significantly inhibited by cyanide. With $0.2 \mathrm{mM}$ cyanide added, only $0.2 \mathrm{mM}$ aniline was degraded in $30 \mathrm{~h}$, and $80 \mu \mathrm{M}$ benzoate aceumulated. Under the same conditions, also 4-aminobenzoate degradation resulted in benzoate accumulation; $0.49 \mathrm{mM} 4$ aminobenzoate degraded were converted to $0.46 \mathrm{mM}$ benzoate within $30 \mathrm{~h}$ (Fig. 3). Cyanide at higher concentrations $(0.2-0.6 \mathrm{mM})$ inhibited aniline and 4aminobenzoate degradation in a similar manner, but less benzoate accumulated.

\section{Isotope exchange between ${ }^{14} \mathrm{CO}_{2}$ and the carboxylic group} of 4-aminobenzoate

In an assay mixture containing $100 \mathrm{mg}$ protein, $5 \mathrm{mM}$ $\mathrm{HCO}_{3}^{-}$(labeled and unlabeled) and $2.5 \mathrm{mM} 4$-aminobenzoate (details see Materials and methods), no significant increase of acid-stable radioactivity was found within $4 \mathrm{~b}$. Addition of inorganic phosphate, $\mathrm{MnCl}_{2}$, or EDTA had no influence. Control experiments with the phenol-degrading Pseudomonas sp. strain S100 (Tschech and Fuchs 1989) showed an isotope exchange of $50 \mathrm{nmol}$ ${ }^{14} \mathrm{CO}_{2}$ exchanged per minute and $\mathrm{mg}$ protein into the carboxyl group of 4-hydroxybenzoate.

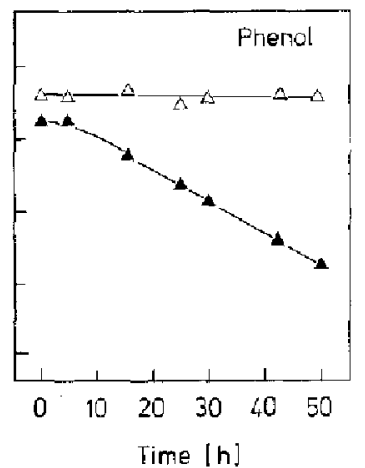

Fig. 2. Degradation of aniline, 4-aminobenzorte, and phenol by dense cell suspensions in the absence of $\mathrm{CO}_{2}$ and with $30 \mathrm{mM} \mathrm{HCO}_{3}^{-}$added. $\mathrm{O}$, Aniline; $\square, \square$ 4-aminobenzoate; $\Delta$, $\Delta$ phenol; $\mathrm{O}, \Gamma, \triangle \mathrm{CO}_{2}$-free assays; - $\mathbf{\square}, \mathbf{\Lambda}$ assays with $30 \mathrm{mM} \mathrm{HCO}-$ atded
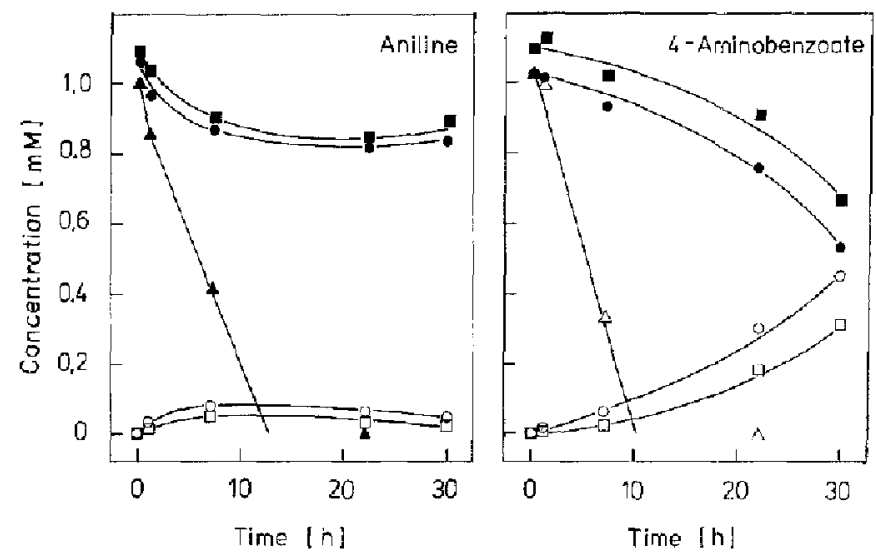

Fig. 3. Degradation of aniline and 4-aminobenzoate by dense cell suspensions inhibited with cyanide. Aniline $(\boldsymbol{A})$ and 4 -aminobenzoate $(\Delta)$ degradation in assays without cyanide; $(\bullet)$ aniline and 4-aminobenzoate degradation and benzoate ( $O$ ) accumulation in assays with $0.2 \mathrm{mM}$ cyanide; ( $)$ aniline and 4-aminobenzoate degradation and benzoate ( $\square$ ) accumulation in assays with $0.4 \mathrm{mM}$ cyanide

\section{Synthesis and hydrolysis of 4-aminobenzoyl-CoA}

4-Aminobenzoyl-CoA was prepared chemically after Merkel et al. (1989). Formation of 4-aminobenzoyl-CoA from $5 \mu \mathrm{mol} \mathrm{CoASH}$ and $10 \mu \mathrm{mol} 4$-aminobenzoic anhydride was followed by HPLC. The reaction was incom- 

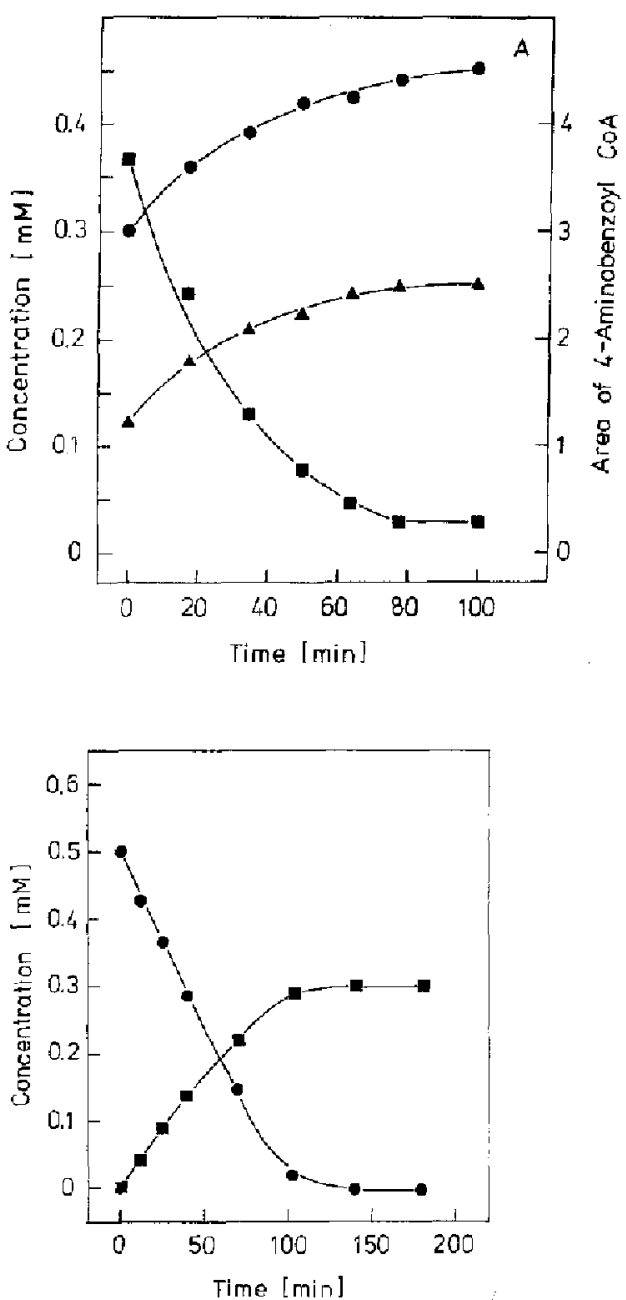

Fig. 5. Time course of 4-aminobenzoatc (9) activation to 4aminobenzoyl-CoA ( $\mathbf{\square}$ ) by cell-free extract of Desulfobacterium anilini

plete; $3.5 \mu \mathrm{mol}$ CoASH and $3.6 \mu \mathrm{mol}$ 4-aminobenzoate were converted lo 4-aminobenzoyl-CoA, while $1.5 \mu \mathrm{mol}$ $\mathrm{CoASH}$ and $6.4 \mu \mathrm{mol} 4$-aminobenzoate remained. For exacl quantification of 4-aminobenzoyl-CoA, an aliquor was hydrolyzed in $0.2 \mathrm{M} \mathrm{NaOH}$. The kinetics of the reaction is shown in Fig. 4A. 0.15 mM 4-Aminobenzoate and $0.13 \mathrm{mM}$ CoASH were formed indicating that 3.39 area units of 4-aminobenzoyl-CoA correspond to $0.14 \mathrm{mM} 4$ aminobenzoyl-CoA. An UV-spectrum of purilied 4-aminobenzoyl-CoA is shown in Fig. $4 \mathrm{~B}$.

\section{4-Aminobenzoyl-CoA synthetase}

4-Aminobenzoyl-CoA synthetase was determined at an activity of $15.8 \mathrm{nmol} \cdot \mathrm{min}^{-1} \cdot \mathrm{mg}^{-1}$ in extracts of aniline-grown cells and of $28.3 \mathrm{nmol} \cdot \mathrm{min}^{-1} \cdot \mathrm{mg}^{-1}$ in extracts of 4-aminobenzoate-grown cells. The kinetics of 4aminobenzoatc activation are shown in Fig. 5. The reaction depended on ATP and CoASH; neither GTP, acetylCoA, or succinyl-CoA could replace ATP or CoASH in the assay mixture. $3 \mathrm{mM}$ AMP in the presence of $1 \mathrm{mM}$ ATP inhibited 4-aminobenzoate activation by $90 \%$. No
Table 1. 4-Aminobenzoyl-CaA synthetase activity in extracts of Destlfobacterium anilini cells grown with aniline under various conditions. 4AB: 4-aminobenzoate

\begin{tabular}{|c|c|}
\hline Conditions & $\begin{array}{l}\text { Activity } \\
{\left[\mathrm{nmol} \cdot \min ^{-1}\right.} \\
\left.\cdot \mathrm{mg}^{-1}\right]\end{array}$ \\
\hline $0.05 \mathrm{mM} 4 \mathrm{AB}, 0.25 \mathrm{mM}$ CoASH, $1 \mathrm{mM}$ ATP & 1.2 \\
\hline $0.1 \mathrm{mM} 4 \mathrm{AB}, 0.5 \mathrm{mM}$ COASH, $1 \mathrm{mM}$ ATP & 13.9 \\
\hline $0.25 \mathrm{mM} 4 \mathrm{AB}, 1 \mathrm{mM}$ COASH, $1 \mathrm{mM}$ ATP & 10.5 \\
\hline $0.5 \mathrm{mM} 4 \mathrm{AB}, 2 \mathrm{mM} \mathrm{COASH}, 2 \mathrm{mM}$ ATP & 9.8 \\
\hline $1 \mathrm{mM} 4 \Lambda \mathrm{B}, 4 \mathrm{mM}$ CoASH, $4 \mathrm{mM}$ ATP & 9.8 \\
\hline $0.5 \mathrm{mM} \mathrm{4AB}, 0.5 \mathrm{mM} \mathrm{Co \Lambda SH}$ & 0 \\
\hline $0.5 \mathrm{mM} 4 \mathrm{AB}, 1 \mathrm{mM} \mathrm{ATP}$ & 0 \\
\hline $0.5 \mathrm{mM} 4 \mathrm{AB}, 0.5 \mathrm{mM}$ acetyl-CoA & 0 \\
\hline $0.5 \mathrm{mM} 4 \mathrm{AR}, 0.5 \mathrm{mM}$ succinyl-CoA & 0 \\
\hline $\begin{array}{l}0.5 \mathrm{mM} 4 \mathrm{AB}, 0.5 \mathrm{mM} \text { CoASH, } 1 \mathrm{mM} \text { ATP, } \\
3 \mathrm{mM} \text { AMP }\end{array}$ & 2.3 \\
\hline $0.5 \mathrm{mM} 4 \mathrm{AB}, 0.5 \mathrm{mM}$ CoASH, $1 \mathrm{mM} \mathrm{GTP}$ & 0 \\
\hline $\begin{array}{l}3 \mathrm{mM} \text { aniline, } 30 \mathrm{mM} \mathrm{HCO}-0.5 \mathrm{mM} \\
\mathrm{COASH}, 2 \mathrm{mM} \text { ATP }\end{array}$ & 0 \\
\hline
\end{tabular}

synthetase activity was found with aniline and $\mathrm{HCO}_{3}^{-}$as substrate (Table 1). The same activity was measured with cell extract treated with air for $5 \mathrm{~min}$, but no activity remained after boiling for $15 \mathrm{~min}$. With substrate concentrations of $10 \mu \mathrm{M}$ to $0.5 \mathrm{mM} 4$-aminobenzoate, the same activities of 4-aminobenzoyl-CoA synthetase were determined indicating that the $K_{\mathrm{m}}$ for 4 -aminobenzoate was lower than $10 \mu \mathrm{M}$. In extracts of aniline- and 4-aminobenzoate-grown cells, the activity of 4-aminobenzoylCoA synthetase was found to be proportional to the amount of extract protein up to $230 \mu \mathrm{g}$ protein per assay. Cell extracts of aniline-grown cultures also activated 2-hydroxybenzoate, 4-hydroxybenzoate, and benzoate to the corresponding CoA derivatives; low activities were measured with 2-aminobenzoate and 3-hydroxybenzoate, and no activity was found with 3-aminobenzoate. 4-Aminobenzoate-grown cells showed good synthetase activity also for 2-aminobenzoate (Table 2). Pyrophosphatase activity was found at $41 \mathrm{nmol} \cdot \mathrm{mg}^{-1}$. $\min ^{-1}$. 
Table 2. Acyl-CoA synthetase specificity for various aromatic acids in cell extracts of Desulfobacterium anilini grown with aniline of 4-aminobenzoate

\begin{tabular}{lll} 
Growth substrate & $\begin{array}{l}\text { Substrate in } \\
\text { activation assay }\end{array}$ & $\begin{array}{l}\text { Activity } \\
{\left[\mathrm{nmol} \cdot \mathrm{min}^{-1}\right.}\end{array}$ \\
\hline Aniline & & $\left.\mathrm{mg}^{-1}\right]$ \\
& 4-aminobenzoate & 15.8 \\
& 2-aminobenzoate & 0.8 \\
& 4-hydroxybenzoate & 24.2 \\
2-hydroxybenzaate & 5.4 \\
& 3-hydroxybenzoate & 1.0 \\
& benzoate & 18.2 \\
4-Aminobenzoate & 4-aminobenzoate & 28.3 \\
& 2-aminobenzoate & 19.9 \\
\hline
\end{tabular}

\section{Reductive deamination of 4-aminobenzoyl-CoA} to benzoyl-CoA

The reductive deamination of 4-aminobenzoyl-CoA to benzoyl-CoA was measured in assays in which 4aminobenzoyl-CoA was synthesized by the coll extract. Consumption of 4-aminobenzoate, and formation of 4aminobenzoyl-CoA and benzoyl-CoA were followed in the presence of several electron donors (Table 3). Optimal conversion of 4-aminobenzoate to 4-aminobenzoyl-CoA, and reduction to benzoyl-CoA were determined with titanium citrate as electron donor. With NADH, NADPI, or reduced benzyl viologen, only little amounts of benzoyl-CoA were produced. With reduced methyl viologen, cobalt sepulchrate, anthraquinone 2,6-disulfonate, neutral red, salranin $T$, and bipyridyl, no 4-aminobenzoylCoA formation was observed, but benzoyl-CoA increased from 3.8 to $17.7 \mu \mathrm{M}$. No reductive deamination was found with propylviologen sulfonate, formate, $\mathrm{H}_{2}$, or $\mathrm{FADH}_{2}$. 4-Aminobenzoatc and 4-aminobenzoyl-CoA were not reduced by any electron donor in the absence

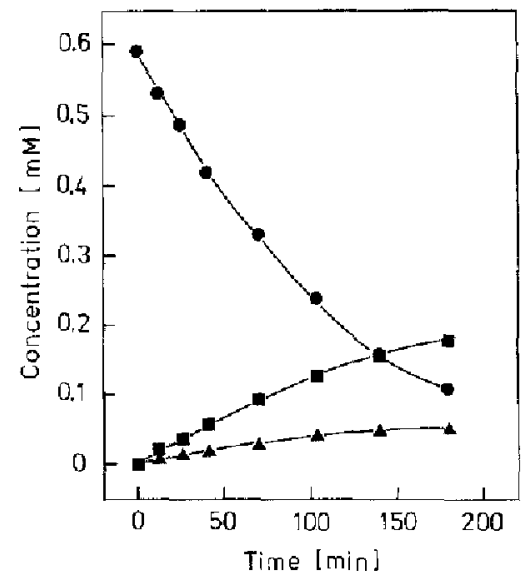

Fig. 6. Kinetics of 4-aminobenzoyl-CoA ( $\boldsymbol{a}$ ) production from 4 . aminobenzoate ( $)$ and coenzyme $A$, and simultaneous reductive dcamination to benzoyl-CoA (A). The assay mixture contained $0.5 \mathrm{mM}$ 4-aminobenzoate, $0.5 \mathrm{mM} \mathrm{CoA,} 1 \mathrm{mM} A T P, 1 \mathrm{mM} \mathrm{ti}$ tanium citrate and $0.17 \mathrm{mg}$ cell protein in $1 \mathrm{ml}$

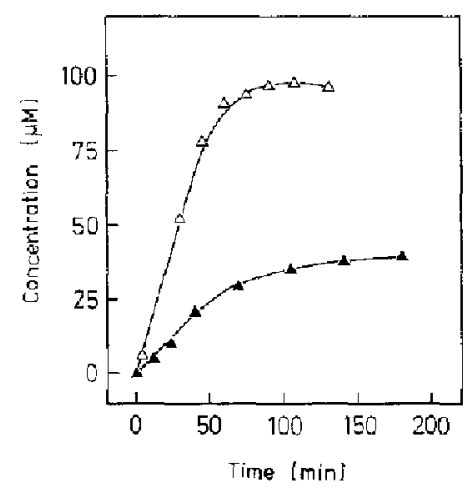

Fig. 7. Benzoyl-CoA formation in an assay with chemically synthesized 4-aminobenzoyl-CoA ( $A)$, and in a coupled assay with 4-aminobenzoatc aclivation and simulaneous reductive deamination of the produced 4-aminobenzoyl-CoA $(\boldsymbol{\Lambda})$ by cell-free extracts with titanium cilrate as electron donor

Table 3. Reductive deamination of 4-aminobenzoyl-CoA to benzoyl-CoA with various electron donors by extracts of aniline-grown cells of Desulfobacteritum anilini in an assay containing $0.5 \mathrm{mM}$-aminobenzoale. $0.5 \mathrm{mM}$ CoASH, and $1 \mathrm{mMI}$ ATP. The amount of remaining 4-aminobenzoate (4AB) and of produced 4-aminobenzoyl-CoA and benzoyl-CoA were determined after $120 \mathrm{~min} .(\mathrm{n} . \mathrm{d} .=$ not determined)

\begin{tabular}{|c|c|c|c|}
\hline Electron donor & $\begin{array}{l}\text { Difference between initial } \\
\text { and final } 4 \Lambda B \text { concentration } \\
{[\mu \mathrm{M}]}\end{array}$ & $\begin{array}{l}\text { 4- } \Lambda \text { minobenzoyl-CoA } \\
\text { produced }[\mu \mathrm{M}]\end{array}$ & $\begin{array}{l}\text { Benzoyl-CoA produced } \\
{[\mu \mathrm{M}]}\end{array}$ \\
\hline $\mathrm{NADH}$ & 90 & 85 & 1.4 \\
\hline NADPH & 120 & 69 & 2.6 \\
\hline Methylviologen & 290 & 0 & 3.8 \\
\hline Cobalt-sepulchrate & 60 & 0 & 12.2 \\
\hline Anthraquinone-2.6-disulfonate & 60 & 0 & 10.2 \\
\hline Neutral red & 70 & 0 & 10.6 \\
\hline Saftanin $T$ & 50 & 0 & 17.7 \\
\hline Bipyridyl & 20 & 0 & 9.4 \\
\hline Propylviologen sulfonate & 50 & 43 & 0 \\
\hline Formatic & 70 & 63 & 0 \\
\hline
\end{tabular}



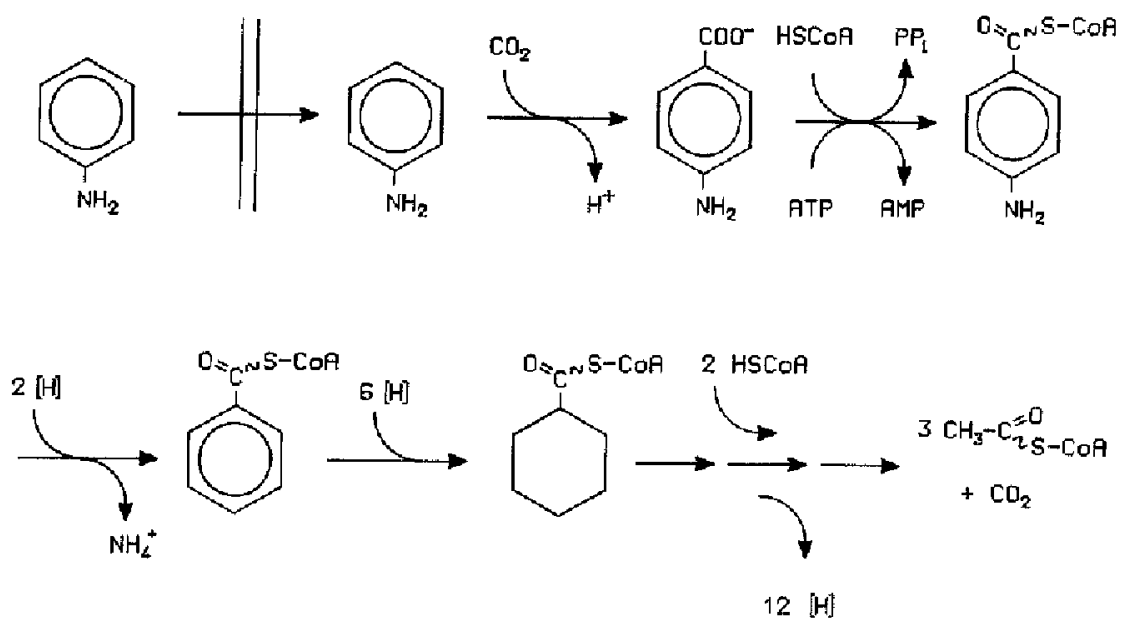

Fig. 8. Pathway of anacrobic aniline degradation by Desulfohacterium anilini as proposed from the results of this study of cell extract. Cell cxtract treated for 5 min with air showed $60 \%$ of the activity found in cell extract kept anoxic. With boiled cell extract, no reductive deamination of 4-aminobenzoyl-Co $\Lambda$ was observed. The kinetics of 4aminobenzoyl-CoA production and simultaneous reductive deamination to benzoyl-CoA are shown in Fig. 6 . The activity of benzoyl-CoA formation in this assay was $2.13 \mathrm{nmol} \cdot \mathrm{min}^{-1} \cdot \mathrm{mg}^{-1}$ protein. With chemically synthesized 4-aminobenzoyl-CoA (initial concentration $370 \mu \mathrm{M})$, a significantly higher activity of benzoyl-CoA formation was determined (Fig. 7).

\section{Discussion}

This study gives the first report on the inilial reactions involved in anaerobic aniline degradation by Desul/obacterium anilini. The first step appears to be a carboxylation to 4-aminobenzoate, followed by activation of 4aminobenzoate to 4-aminobenzoyl-CoA. 4-Aminobenzoyl-CoA is reductively deaminated to benzoyl-CoA which enters the normal benzoate pathway, leading to three acelyl-CoA. In $D$. anilini, $C O$-dehydrogenase and formate dehydrogenase activities of 3.6 and $4.0 \mu \mathrm{mol}$. $\min ^{-1} \cdot$ mg protein ${ }^{-1}$ are present (Schnell et al. 1989) indicating that acetyl residues are oxidized via the $\mathrm{CO}$ dehydrogenase pathway (Schauder et al. 1986). The proposed pathway for aniline degradation by $D$. anilini is shown in Fig. 8.

Carboxylation of aniline to 4-aminobenzoate is indicated by $\mathrm{CO}_{2}$ dependence of aniline degradation in dense cell suspensions, different from 4-aminobenzoale degradation, which is independent of $\mathrm{CO}_{2}$. Accumulation of benzoate by cell suspensions degrading aniline or 4aminobenzoate in the presence of cyanide or under conditions of sulfate limitation provides a further hint for a carboxylation activity. Also induction experiments indicaled the existence of a common pathway for degradation of aniline and 4-aminobenzoate, different from those of 2aminobenzoate, 2-hydroxybenzoate, 4-hydroxybenzoate, and phenol degradation.

Carboxylation as initial step in degradation of aromatic compounds has so far been reported only for phe- nols. Benzoate was formed from phenol and $\mathrm{CO}_{2}$ in phenol-degrading sewage sludge in the presence of hydrogen (Knoll and Winter 1987). $\mathrm{CO}_{2}$ was also incorporated during anaerobic melabolism of $m$-cresol by a methanogenic consortium (Roberts et al. 1990). Carboxylation of phenol to 4-hydroxybenzoate was suggested as well on the basis of experiments on isotope exchange between ${ }^{14} \mathrm{CO}_{2}$ and the carboxyl group of 4-hydroxybenzoate by cell extracts of a denitrifying bacterium (Tschech and Fuchs 1989). Failure to detect isotope exchange between the carboxylic group of 4-aminobenzoate and free ${ }^{14} \mathrm{CO}_{2}$ by $D$. anilini does not rule that aniline is carboxylated to 4-aminobenzoate since the isotope exchange is only a side reaction of the carboxylating enzyme that might be displayed individually to a higher or lower extent. A carboxylation has never been demonstrated so far for any aromatic compound neither with intact cells nor with cell extract.

Carboxylation in ortho or para position of aniline is chemically preferred over that in meta position. Extracts of aniline-grown cells activated only 4-aminobenzoate and benzoate to the corresponding acyl-CoA derivatives, whereas 2-aminobenzoate was activated only at very low activity. The same cells possessed an acyl-CoA synthetase activity reacting with 4-hydroxybenzoate much better than with 2-hydroxybenzoate or 3-hydroxybenzoate. $\mathrm{Ob}$ viously hydroxy or amino substituents in ortho (2aminobenzoatc, 2-hydroxybenzoate) or meta (3-hydroxybenzoate) position interfere sterically with the acyl-CoA synthetase induced by aniline-grown cells; the acyl-CoA synthetase of 4-aminobenzoate-grown cultures also activated 2 -aminobenzoate and therefore showed a different catalytic property. The activity of 4-aminobenzoate activation measured in extracts of aniline-grown cells was $16.5 \mathrm{nmol}^{\prime} \mathrm{min}^{-1} \cdot \mathrm{mg}^{-1}$, about $24 \%$ of the calculated in vivo activity $\left(70 \mathrm{nmol} \cdot \mathrm{min}^{-1} \cdot \mathrm{mg}^{-1}\right)$.

Aclivation of aromatic acids to their CoA derivatives before anaerobic breakdown was observed so far in benzoate degradation by Rhodopseudomonas palustris (Harwood and Gibson 1986), 2-aminobenzoate degradation by a denitrifying Pseudomonas strain (Ziegler ot al. 1987) and 4-hydroxybenzoate degradation by denitrifying bacteria (Merkel et al. 1989; Glöckler et al. 
1989). It is remarkable that also the comparably encrgylimited sulfate reducer $D$. anilini used a synthetase reaction for 4-aminobenzoate activation; due to the pyrophosphatase activity present, this activation is accomplished at the high expense of two ATP equivalents. One can speculate that this highly exergonic activation reaction with its high substrate affinity maintains an extremly low 4-aminobenzoate concentration and pulls the initial carboxylation reaction; the overall reaction:

$$
\begin{aligned}
\text { Aniline } & +\mathrm{CO}_{2}+\Lambda \mathrm{TP}+\mathrm{COASH} \\
& \rightarrow 4-\mathrm{Aminobenzoyl}-\mathrm{COA}+\mathrm{AMP}+2 \mathrm{P}_{\mathrm{i}}
\end{aligned}
$$

is cstimated (by comparison with the activation of acetate to acetyl-CoA) to be close to equilibrium under standard conditions $\left(\Delta \mathrm{G}_{0}^{\prime}=-3 \mathrm{~kJ} \cdot \mathrm{mol}^{-1}\right.$; Thauer et al. 1977). Such a direct coupling of endergonic carboxylation with exergonic CoA-activation and ATP-hydrolysis would require a 4-aminobenzoatc to aniline concentration ratio of about $10^{4}: 1$, and would explain why 4-aminobenzoate could never be detected in our assays. Proof of the carboxylation reaction, e. g. by pulse-chase experiments with radiolabelled aniline, can be obtained only when this reaction becomes measurable in cell-free extract.

After carboxylation to 4-aminobenzoate and activation to 4-aminobenzoate-CoA, the subsecquent step in aniline degradation was reductive elimination of the amino group. Reductive elimination reactions were postulated first for fermentative degradation of 3-hydroxybenzoate in defined syntrophic cocultures (Tschech and Schink 1986), and for 2-aminobenzoate (anthranilate) degradation by methanogenic enrichment cultures (Tschech and Schink 1988). Also the fermenting bacterium $\mathrm{HQG} \ddot{1} 1$ appears to degrade gentisate via reductive dehydroxylation to benzoate and acelate (Szewzyk and Schink 1989). The only reductive elimination studied so far in cell-free extracts is the dehydroxylation of 4hydroxybenzoyl-CoA by a denitrifying Pseudomonas sp. (Glöckler et al. 1989).

In cell extracts of $D$. anilini, reductive deamination of 4-aminobenzoyl-CoA to benzoyl-CoA was possible with titanium citrate or other low-potential electron donors. The reaction in the coupled assay consisting of 4aminobenzoate, CoASH, ATP, and titanium citrate was limited by the production of 4-aminobenzoyl-CoA; the activity was low $\left(2.3 \mathrm{nmol} \cdot \mathrm{min}^{-1} \cdot \mathrm{mg}^{-1}\right)$ compared to that determined in an assay with $370 \mu \mathrm{M}$ of chemically synthesized 4-aminobenzoyl-CoA $8.1 \mathrm{nmol} \cdot \min ^{-1}$. $\mathrm{mg}^{-1}$ ). Obviously the affinity of the reductase for 4aminobenzoyl-CoA and titanium citrate is low. As long as the physiological electron donor of the reductase reaction is unknown, the reaction kinetics cannot be studied in any morc detail. Perhaps the enzyme is membranebound and hard to provide with electrons in our test assay; this hypothesis could explain why also the measured activity is low in comparison to the calculated in vivo activity of 4-aminobenzoate-grown cells (127 nmol $\min ^{-1} \cdot \mathrm{mg}^{-1}$ protein).

Acknowledgements. We thank Dr. Andreas Brune for continuous helpful discussions, and Dr. Andreas Tschech for support with the isotope exchange experiments. This work was supported by a grant of the Deutsche Forschungsgemeinschaft.

\section{References}

Aoki $\mathrm{K}$, Kemori $\mathrm{T}$, Shinke R, Nishira $\mathrm{H}$ (1985) Further characterization of bacterial production of anthranilic acid from aniline. Agric Biol Chem 49:1151-1158

Backofer R, Lingens F, Schäfer W (1975) Conversion of aniline into pyrocatechol by Nocardia sp., incorporation of oxygen-18. FFBS Lett 50:288-290

Bollag TM, Russel S (1976) Aerobic versus anaerobic metabolism of halogenate anifines by a Paracoccus sp. Microbiol Ecol $3: 65-73$

Bradford MM (1976) A rapid and sensilive method for the quantitation of microgram quantities of protein utilizing the principle of protein-dye binding. Anal Biochem 72:248-254

Franck HG, Stadelhofer IW (1987) Industrielle Aromatenchemie. Springer, Berlity Heidelberg New York

Glöckler R, Tschech A. Fuchs G (1989) Reductive dehydroxylation of 4-hydroxybenzoyl-CoA to benzoyl-CoA in a denitrifying, phenol degrading Pseudomonas specics. FERS Lett 251:237240

Hallas LE, Alexander M (1983) Microbial transformation of nitroaromatic compounds in sewage effluent. Appl Environ Microbiol 45:1234-1241

Harwood CS, Gibson J (1986) Uptake of benzoate by Rhodopseudomonas palustris grown anaerobically in light. J Bacteriol 165:504-509

Herberf D, Phipps PJ Strange RE (1971) Chemical analysis of microbial cells. In: Norris JR, Ribbons DW (cts) Methods in microbiology, vol 5B. Academic Press, New York, pp 209344

Janke D, Al-Mofarii, Straube G, Schuman P, Prauser H (1988) Critical steps in degradation of chloroaromatics by rhodococci. I. Initial enzyme reactions involved in catabolism of aniline, phenol and benzoate by Rholococens sp. An117 and An213. J Basic Microbiol 28:509-518

Knoll $G$, Winter J (1987) Anaerobic degradation of phenol in sewage sludge. Benzoate formation from phenol and $\mathrm{CO}_{2}$ in the presence of hydrogen. Appl Microbiol Biotechnol 25:384391

Merkel SM, Eberlaard AE, Gibson J, Harwood CS (1989) Involvement of Coenzyme A thioesters in anaerobic metabolism of 4-hydroxybenzoate by Rhodopseudomonas palustris. J Bacteriol $171: 1-7$

Platen $H$ (1989) Abbau von Aceton und höheren aliphatischen Kctonen durch anacrobe Bakterien. PhD thesis, Tübingen, FRG

Reber H, Helm V, Karanth NGK (1979) Comparative studies on the metabolism of aniline and chloroaniline by Pseudomonas multivorans strain An1. Eur J Appl Microbiol Biotechnol $7: 181-189$

Roberts DJ, Fedorak PM, Hrudey SE (1990) $\mathrm{CO}_{2}$ incotporation and 4-hydroxy-2-methylbenzoic acid formation during anacrabic metabolism of m-ctesol by a methanogenic consortium. Appl Enviton Microbiol 56: $472-478$

Schauder R, Eikmanns B, Thatuer RK. Widdel F, Fuchs G (1986) Acetate oxidation to $\mathrm{CO}_{2}$ in anaerobic bacteria via a novel pathway not involving reactions of the citric acid cycle. Arch Microbiol 145:162-172

Schnell S, Bak F, Pfennig N (1989) Anacrobic degradation of aniline and dihydroxybenzenes by newly isolated sulfate-reducing bacteria and description of Desulfobactertum anilini. Arch Microbiol 152:556 - 563

Szewzyk U, Schink B (1989) Degradation of hydroquinonc, gentisate, and benzoate by a fermenting bactorium in pure or defined mixed culture. Arch Microbiol 151:541-545

Thawer RK, Jungermann K, Decker K (1977) Energy conservation in chemotrophic anaerobic bacteria. Bacteriol Rev 41:100180

Thebrath B, Dilling W, Cypionka $\mathrm{H}$ (1989) Sulfate activation in Desulfotomaculum. Arch Microbiol 152:296-301 
Tschech A, Fuchs G (1989) Anaerobic degradation of phencl via carboxylation to 4-hydroxybenzoate: in vitro study of isotope exchange between ${ }^{14} \mathrm{CO}_{2}$ and 4hydroxybenzoate. Arch Microbial 152:594-599

Tschech A, Schitk B (1986) Fermentative degradation of monohydroxybenzoates by defined syntrophic cocultures. Arch Microbiol 145:396-402

Tschech A, Schink B (1988) Methanogenic degradation of anthranilate (2-iminobenzoate). Syst Appl Microbiol 11:9-12
Webster LT, Mieyal JJJ, Siddiqui UA (1974) Benroyl and hydroxybenzoyl esters of Coenzyne A. J Biol Chem $249: 2641-$ 2645

Wyndham RC (1986) Evolved aniline catabolism in Acinetobacter calcoaceticts during continuous culture of river water. Appl Environ Microbiol 51:781 - 789

Ziegler K, Braun K, Böckler A, Fuchs G (1987) Studies on the anaerobic degradation of benzoic acid and 2 -aminobenzoic acid by a denitrifying Pseudomonas strain. Arch Microbiol 149:62-69 